\title{
Effects of sulfate concentration on Emiliania huxleyi growth in current and past ocean
}

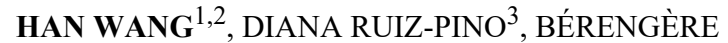

BROCHE $^{2,3}$, IAN PROBERT ${ }^{4}$ AND SILVIA GARDIN ${ }^{2}$

${ }^{1}$ Sorbonne Université

${ }^{2} \mathrm{SU}, \mathrm{CNRS}, \mathrm{MNHN}$

${ }^{3} \mathrm{SU}, \mathrm{CNRS}, \mathrm{MNHN}, \mathrm{IRD}$

${ }^{4} \mathrm{SU}, \mathrm{CNRS}$

Presenting Author: han.wang@locean.ipsl.fr

Changes in sulfur concentration in the ocean produced by both volcanoes and anthropogenic inputs, may produce different impacts on pelagic calcifies tests according to seawater chemistry (aragonite vs calcite seas, whose boundary is defined as $\mathrm{Mg} / \mathrm{Ca}$ ratio $=2[1])$.

This work tests in in-vitro laboratory experiments the effects of 2 chemical changes, $\mathrm{Mg} / \mathrm{Ca}$ and Sulfur [sulfate] on the calcification and growth of the greatest calcite producing organisms in the ocean, the coccolithophores. Original Batch cultures were used to reproduce the growth of clones of Emiliania huxleyi in artificial seawater conditions reproducing the modern configuration (high $\mathrm{Mg} / \mathrm{Ca}$ ratio 5.2, low $\mathrm{Ca}$ of $10.5 \mathrm{mM}$ ) and two different Cretaceous-like ocean configurations (calcite-sea period): $\mathrm{K} 1$ with $\mathrm{Mg} / \mathrm{Ca}=1$ and $\mathrm{Mg}$ and $\mathrm{Ca}$ concentration as $25 \mathrm{mM}$; $\mathrm{K} 3$ with $\mathrm{Mg} / \mathrm{Ca}=1$ but low $\mathrm{Mg}$ and $\mathrm{Ca}$ concentration $(=10.5 \mathrm{mM})$. The $3 \mathrm{Mg} / \mathrm{Ca}$ conditions are submitted to increasing sulfates concentration from $5 \mathrm{mM}$ to $180 \mathrm{mM}$, to simulate the functioning of Cretaceous and modern oceans facing the highest input of sulfur.

Modern conditions resulted to be more favorable to calcification and larger cells than those of $\mathrm{K} 3$ sea but provided smaller and less calcified cells than those of K1 sea. At low sulfates, $\mathrm{K} 1$ is more favorable for the precipitation of calcite than modern conditions. Calcification was strong in the Cretaceous calcite sea's conditions when sulfates were also low $(5 \mathrm{mM}$ and $17 \mathrm{mM}$ ) and has only decreased in modern $\mathrm{Mg} / \mathrm{Ca}$ ratio.

$\mathrm{K} 3$ experimental results suggest that low $\mathrm{Mg} / \mathrm{Ca}$ ratio with low Ca concentration in the past, when associated with high sulfur inputs, could have played a role in driving one of the greatest biocalcification crises (Cretaceous crisis, 66.04Ma) in past ocean. On the opposite, K1 could reproduce conditions of flourishing of high diversity and high calcification rate during the Cretaceous. The result of our experiment opens the question whether different coccolith species would have similar behavior to chemical changes in ocean as modern Emiliania huxelyi and if all known biocalcification crises in the past were linked to changes in both sulfate and $\mathrm{Mg} / \mathrm{Ca}$.

[1] Goldschmidt, Stanley \& Hardie (1999), GSA today, 9(2), $1-7$. 